\title{
Study of total Immunoglobulin E and Eosinophil count in allergic disease
}

\author{
Suaad A. Brakhas* \\ Amna N. Jassim** \\ *Department of Immunology, Allergy Specialized Center, Baghdad, Iraq. \\ ** Department of Biology, College of Science for Women, University of Baghdad \\ Received 22/4/ 2015 \\ Accepted 9/7/ 2015 \\ (c) $($ i) (3) \\ This work is licensed under a Creative Commons Attribution-NonCommercial- \\ $\underline{\text { NoDerivatives 4.0 International Licens }}$
}

\begin{abstract}
:
The present study aimed to evaluate the levels of total immunoglobulin $\mathrm{E}$ and percentage count of eosinophil in some of allergic disease. Blood sample collected from 210 patients (110 female, 100 male) with allergic disease (allergic asthma, allergic rhinitis, and urticaria) their age between 10-70 years and 50 healthy control their age between 23-52 years. A highly significant $(\mathrm{P}<0.01)$ increase in the mean serum total $\mathrm{IgE}$ in patients with asthma $(503.54 \pm 63.49 \mathrm{IU} / \mathrm{ml})$, Allergic rhinitis $(442.77 \pm 95.76 \mathrm{IU} / \mathrm{ml})$ and urticaria $(489.53 \pm 69.68 \mathrm{IU} / \mathrm{ml})$ as a compared with healthy controls $(23.67 \pm 5.81 \mathrm{IU} / \mathrm{ml})$. There was a significant difference in percentage count of eosinophil in patients groups allergic asthma $4.37 \pm 0.52 \%$,allergic rhinitis $4.38 \pm 0.50 \%$, and urticaria $4.12 \pm 0.43 \%$ as compared to healthy control $2.57 \pm$ $0.86 \%$. The mean of serum total IgE levels and eosinophil counts may be helpful in the diagnosis of allergic disease.
\end{abstract}

Key words: Asthma, Rhinitis, Urticaria, Immunoglobulin E, Eosinophil.

\section{Introduction:}

Allergic and Type I hypersensitivity reactions are the results of immune response to allergens, This response is mediated by $\operatorname{IgE}$ antibody specific to the allergen, Mast cells and basophiles are activated after IgE bindings, starting a serious of cellular and molecular events that results in the clinical manifestation of allergic diseases [1]. Asthma is a chronic allergic disorder of the airways, in which many cells and cellular elements play a role in particular mast cells. The inflammation causes recurrent symptoms of breathlessness, wheezing, chest tightness and cough, usually there is a widespread airflow obstruction with these episodic symptoms, which is reversible to varying degrees either spontaneously or with treatment [2]. Allergic rhinitis is an acute IgE mediated type I hypersensitivity reaction of nasal mucosa in response to antigenic substances (allergens) associated with episodic attacks of sneezing, watery rhinorrhea and watering of the eyes, patients also present tightness of chest, due to subclinical bronchospasm [3]. Urticaria (hives) is a common disorder, occurring in $15-25 \%$ of individuals at 
some point in life, it is characterized by recurrent, pruritic (itchy), pink-to-red edematous (swollen) lesions that is often have pale centers (wheals). The lesions can range in size from a few millimeters to several centimeters in diameter, and are often transient, lasting for less than 48 hours [4].

IgE determination is valuble in the diagnosis of allergic diseases such as, asthma, allergic rhinitis, urticaria, atopic dermatitis and some parasitic infections which leads to increase IgE levels [5]. Among the non-infectious diseases associated with eosinophilia are allergic diseases, including allergic rhinitis, conjunctivitis, and asthma, eosinophils are present in involved tissues as well as increase in blood [6]. The eosinophil is a multifunctional leukocyte playing a central role in Th2 mediated allergic diseases. parasitic killing and tissue repair[7]. Recent studies have pointed out eosinophil involvement in modulating both innate and adaptive immune responses [8]. Previous studies demonstrated that, the number of eosinophils is increased in blood and tissue in patients with atopic diseases $[9,10]$. Many investigators used total $\operatorname{IgE}$ and eosinophil count for evaluating allergic diseases $[11,12,13]$. The aim of this study is to investigate the role T-IgE level and Eosinphil count in patients with allergic asthma; allergic rhinitis and allergic urticaria compared to the healthy control.

\section{Material and Methods:}

This study was carried out at the allergy specialized center in Baghdad/ALResafa from April 2014 to September 2014, 210 patients with allergic disease were classified into three groups, (77 Asthma, 48 Rhinitis, and 85 Urticaria) and 50 individual as a healthy control. Both physical and clinical examinations were done for each subject and the information was recorded in a data sheet.
Blood samples were collected for estimation of serum total $\operatorname{IgE}$ by sandwich ELISA, read the results automatically by ELISA readers, using kit from Dr.Foke (Germany), the value over $100 \mathrm{IU} / \mathrm{ml}$ were considered high and the eosinophil counts were done by Beckman coulter analyzer, the percentage of eosinophil count below $4 \%$ was used as the reference value for normal levels of eosinophils. The sample results were calculated by using standard curve fitting equations for T-IgE (figure $1)$.

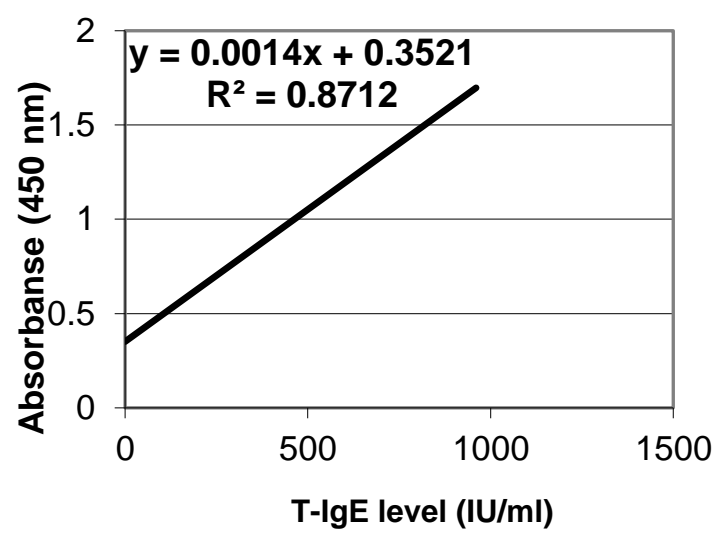

Fig. (1): The Standard Curve of IgE IU/ml

\section{Statistical Analysis:}

The Statistical Analysis System- SAS (2012) was used to effect of different factors in study parameters. Least significant difference -LSD test was used to significant compare between means. Estimate of correlation coefficient between difference parameters in this study [14].

\section{Results:}

The mean level of serum Total IgE levels in study groups are summarized in table (1), there is a highly significant $(\mathrm{P}<0.01)$ increase in the mean of total serum IgE in patients with asthma $(503.54 \pm 63.49 \mathrm{IU} / \mathrm{ml})$, Allergic rhinitis $(442.77 \pm 95.76 \mathrm{IU} / \mathrm{ml})$ and urticaria $(489.53 \pm 69.68 \mathrm{IU} / \mathrm{ml})$ as compared with healthy controls $(23.67 \pm 5.81$ $\mathrm{IU} / \mathrm{ml})$. 
Table (1) The level of total IgE in study groups

\begin{tabular}{|c|c|c|c|}
\hline $\begin{array}{c}\text { Study } \\
\text { groups }\end{array}$ & No. & Range & $\begin{array}{c}\text { T-IgE(IU/ml) } \\
\text { Mean } \pm \text { SE }\end{array}$ \\
\hline $\begin{array}{c}\text { Allergic } \\
\text { asthma }\end{array}$ & 77 & $12-568.32$ & $503.54 \pm 63.49 * *$ \\
\hline $\begin{array}{c}\text { Allergic } \\
\text { rhinits }\end{array}$ & 60 & $10-1000$ & $442.77 \pm 95.76^{* *}$ \\
\hline $\begin{array}{c}\text { Allergic } \\
\text { urticaria }\end{array}$ & 82 & $11.43-1000$ & $489.53 \pm 69.68^{* *}$ \\
\hline $\begin{array}{c}\text { Healthy } \\
\text { control }\end{array}$ & 50 & $10.5-56.61$ & $23.67 \pm 5.81$ \\
\hline LSD value & \multicolumn{4}{|c|}{$246.51 * *$} \\
\hline P-value & $* * 061$ \\
\hline$*$ (P $\leq \mathbf{0 1 0 1 )}$
\end{tabular}

The mean serum T-IgE level according to age groups are shown in table (2). There are a significant $(\mathrm{P}<0.05)$ increase in mean serum level $\mathrm{T}-\mathrm{IgE}$ in patients in age group (30-39 years) with allergic asthma $(558.049 \pm 89.13 \mathrm{pg} / \mathrm{ml})$, allergic rhinitis $(513.934 \pm 72.49 \mathrm{pg} / \mathrm{ml})$, and urticaria $(503.262 \pm 113.7 \mathrm{pg} / \mathrm{ml})$, when compared with healthy controls (42.05 \pm $17.43 \mathrm{pg} / \mathrm{ml})$.

Table (2) Distribution of T-IgE in Allergic patients according to age groups

\begin{tabular}{|c|c|c|c|c|c|c|c|c|}
\hline $\begin{array}{c}\text { Age groups } \\
\text { (years) }\end{array}$ & \multicolumn{2}{|c|}{ Healthy control } & \multicolumn{2}{c|}{ Asthma } & \multicolumn{2}{c|}{ Rhinitis } & \multicolumn{2}{c|}{ Urticaria } \\
\cline { 2 - 9 } & No. & T-IgE & No. & T-IgE & No. & T-IgE & No. & T-IgE \\
\hline$<20$ & 6 & $28.03 \pm 7.59$ & 15 & $\begin{array}{c}365.913 \pm \\
84.37\end{array}$ & 7 & $\begin{array}{c}329.934 \pm \\
79.52\end{array}$ & 7 & $272.88 \pm 54.79$ \\
\hline $20-29$ & 19 & $32.31 \pm 8.34$ & 11 & $486.91 \pm 61.28$ & 12 & $\begin{array}{c}471.823 \pm \\
92.55\end{array}$ & 22 & $\begin{array}{c}461.742 \pm \\
73.94\end{array}$ \\
\hline $30-39$ & 11 & $42.05 \pm 17.43$ & 29 & $\begin{array}{c}558.049 \pm \\
89.13\end{array}$ & 12 & $\begin{array}{c}513.934 \pm \\
72.49\end{array}$ & 24 & $\begin{array}{c}503.262 \pm \\
113.7\end{array}$ \\
\hline $40-50$ & 10 & $23.43 \pm 5.19$ & 18 & $\begin{array}{c}352.958 \pm \\
54.84\end{array}$ & 10 & $\begin{array}{c}245.012 \pm \\
80.17\end{array}$ & 20 & $\begin{array}{c}39.662 \pm \\
64.84\end{array}$ \\
\hline$>50$ & 4 & $30.0 \pm 5.48$ & 4 & $\begin{array}{c}249.608 \pm \\
61.28\end{array}$ & 7 & $\begin{array}{c}191.086 \pm \\
42.77\end{array}$ & 12 & $\begin{array}{c}184.102 \pm \\
39.16\end{array}$ \\
\hline Total & 50 & & 77 & & 48 & & 85 & $181.36 *$ \\
\hline LSD value & -- & 28.91 & -- & $184.39^{*}$ & --- & $241.07 *$ & --- & \\
\hline
\end{tabular}

$*(\mathbf{P} \leq \mathbf{0 . 0 5})$.

There is a significant $(\mathrm{P}<0.05)$ increase in mean serum $\mathrm{T}-\mathrm{IgE}$ in patients, through gender groups compared to the healthy control. Table (3) shows the mean of serum $\mathrm{T}-\mathrm{IgE}$ levels in male increase in asthma $506.025 \pm 138.7$ $\mathrm{IU} / \mathrm{ml}$, while in female increase in rhinitis $511.398 \pm 103.6 \mathrm{IU} / \mathrm{ml}$ and urticaria $412.95 \pm 91.74 \mathrm{IU} / \mathrm{ml}$.

Table (3) Distribution of T-IgE in Allergic patients according to gender groups

\begin{tabular}{|c|c|c|c|c|c|c|c|c|c|}
\hline \multirow[b]{2}{*}{ Gender } & \multicolumn{2}{|c|}{ Healthy control } & \multicolumn{2}{|c|}{ Asthma } & \multicolumn{2}{|c|}{ Rhinitis } & \multicolumn{2}{|c|}{ Urticaria } & \multirow[b]{2}{*}{ Total } \\
\hline & NO. & $\begin{array}{c}\text { T-IgE } \\
(\mathrm{IU} / \mathrm{ml})\end{array}$ & NO. & $\begin{array}{c}\text { T-IgE } \\
\text { (IU/ml) }\end{array}$ & NO. & $\begin{array}{c}\text { T-IgE } \\
\text { (IU/ml) }\end{array}$ & NO. & $\begin{array}{c}\text { T-IgE } \\
\text { (IU/ml) }\end{array}$ & \\
\hline Male & 25 & $\begin{array}{c}24.351 \pm \\
6.22\end{array}$ & 34 & $\begin{array}{c}506.025 \pm \\
138.7\end{array}$ & 19 & $\begin{array}{c}329.328 \pm \\
73.44\end{array}$ & 47 & $\begin{array}{c}212.067 \pm \\
52.69\end{array}$ & 100 \\
\hline Female & 25 & $\begin{array}{c}17.308 \pm \\
4.93\end{array}$ & 43 & $\begin{array}{c}432.185 \pm \\
84.68\end{array}$ & 29 & $\begin{array}{c}511.398 \pm \\
103.6\end{array}$ & 38 & $\begin{array}{l}412.95 \pm \\
91.74\end{array}$ & 110 \\
\hline Total & 50 & & 77 & & 48 & & 85 & & 210 \\
\hline LSD value & -- & 11.38 & -- & $63.47 *$ & -- & $121.59 *$ & -- & $138.91 *$ & --- \\
\hline
\end{tabular}

$*(\mathrm{P} \leq 0.05)$.

As shownin in table (4), there is a significant difference in percentage of eosinophil count in patients groups allergic asthma $4.37 \pm 0.52 \%$,allergic rhinitis $4.38 \pm 0.50 \%$, and urticaria 4.12 $\pm 0.43 \%$ as compared with healthy control $2.57 \pm 0.86 \%$.
Table (4) The percentage of Eosinophil count in study groups

\begin{tabular}{|c|c|c|c|}
\hline Groups & NO. & Range & $\begin{array}{c}\text { Eosin.(\%)Mean } \pm \\
\text { SE }\end{array}$ \\
\hline Allergic asthma & 77 & $1-11$ & $4.37 \pm 0.52^{*}$ \\
\hline Allergic rhinits & 60 & $1-7$ & $4.38 \pm 0.50^{*}$ \\
\hline Urticaria & 82 & $1-9$ & $4.12 \pm 0.43^{*}$ \\
\hline Healthy control & 50 & $2-8$ & $2.57 \pm 0.86$ \\
\hline LSD value & \multicolumn{3}{|c|}{$1.760 *$} \\
\hline P-value & \multicolumn{3}{|c|}{0.0549} \\
\hline
\end{tabular}




\section{Discussion:}

Allergic diseases are characterized by the IgE-dependent release of mast cellderived mediators and cellular infiltration particularly of activated eosinophils and T-lymphocytes [15].

IgE not only provides protective immunity against helminth parasites but also mediate type-1 hypersensitivity reactions, that contribute to the pathogenesis of allergic diseases such as;asthma, allergic rhinitis and atopic dermatitis [16].

There were significant differences in the levels of (T-IgE) among different age groups in asthma, where recorded (30-39 years), the highest level was $558.049 \pm$ $89.13 \mathrm{pg} / \mathrm{ml}$ among other categories represent more active and contact with environmental allergens, these findings are in agreement with the results of [1], in Iraq, who found patients with detectable levels of serum total $\mathrm{IgE}$ $(>100 \mathrm{IU} / \mathrm{ml})$ gradually increased with age, with a maximum being observed in the 31-40 year old group, but the level of T-IgE in allergic disease declined with age after 50 years old, compared with younger subjects, that results were similar with previous studies by [1], [17] and [18], they found a lower prevalence of allergic disease in the most advanced ages, both in control subjects and in individuals affected by allergic respiratory, allergic rhinitis and urticaria. These results are in agreement with [19], who reported showed that most of the rates of allergic were in the age range (27-35) years,and then decreased with age in Iraqi patients. Aging is associated with modifications of the immune system, defines as immunosenescene, this could contribute to a reduce prevalence of allergic diseases in elderly populations [17].

The results of this study showed that allergic disease was different in both genders. Allergic asthma was increased with male more than female, this was in agreement with the study of [20], in
USA, who stated that asthma common in males more than females, while [21], in Pakistan who concluded that the frequency of allergic rhinitis was significantly different in both genders and found in female more than male. The results of the present study are in agreement with in Portugal, [22], who found that there was a female dominance in the studied population for allergic rhinitis, while disagree results of the present study in Iraq [1], where showed that allergic rhinitis was dominant in male more than female due to sample size or environmental effects. These results are in agreement with [23], who showed urticaria in approximately $0.5 \%$ of the general population and has a female preponderance. In Iraq [24], showed that chronic urticaria increased in female more than male and this consistent with the results of the current study.This elevation may be due to hormonal variations in female sex that include (a defect in an endocrinopathy, menstrual cycle, pregnancy, menopause and hormonal contraceptives), environmental or genetic conditions beside the psychological change of Iraqi people which results in highly stress that enhance allergic disease development.

The current study provides additional support to the key role played by IgE in mediating, maintaining, and severity of the allergic response in allergic patients manifested by the elevated levels of IgE compared with healthy control [25].

Where [1] and [26], found an elevated IgE value is suggestive of the diagnosis allergic rhinitis, and explained test results $\mathrm{T}-\mathrm{IgE}$ there is marked increase in levels of this antibody in patients with asthma compared with control . 
The present results are in agreement with the results of [19], who showed a significant differences in total IgE levels between allergic disease and healthy control. [27], found that total IgE levels was a high significant increase in asthma $(453.6 \pm 40.28)$ compared to the healthy control $(105.44 \pm 16.85)$, these results are similar to what was done by [28] in Turkey, showed IgE antibody to be higher in patients with chronic urticaria compared with healthy control.

This may be explained that the allergic diseases, such as allergic asthma, allergic rhinitis and urticaria are characterized by an increased number of eosinophil granulocytes in the circulating blood and degranulation in the target tissue is considered the major pathogenic event [19, 27, 29].

Eosinophils are known to be the main effector cells of allergic process, it is important during the initial and later stages of allergic airway diseases [30]. Bases on the presented results, there is a significant increase in eosinophil count percentage in patients as compared to healthy controls. Several studies have reported that higher serum total IgE levels and eosinophilia were present in patients with allergic disease [31].

\section{Conclusion:}

It has been found that increased levels of T-IgE and eosinophil count in serum of allergic disease. All Iraqi allergic patients with different age level showed significant increased level of total $\operatorname{IgE}$ compared to the healthy controls. The concentration of T-IgEvaried between male and female according to the allergic disease. There was a significant increase in percentage count of eosinophil in patients with allergic asthma, rhinitis and urticaria.

\section{References}

[1]Brakhas, S. A.; Atia, M. R.; Aziz, Y. J. and AL-Sharqi, S. A. H. 2015.
Study of total $\operatorname{IgE}$ levels and eosinophil count according to age and gender in patients with allergic rhinitis. World J Pharm Res., 4(1):295-303.

[2]Abbas, A.; Shahid, S. Sabah, A.; Beg, A. E.; Ahmed, F. R.; Sidra Tanwir, S.; Ahmed, S. W.; Kashif, M.; Jatoi, A. H.; Rizvi, S. A.; and Qidwai, M. A. 2014. The clinical complications of Asthma and its pharmacotherapy. $\mathbf{J}$ British biomelical Bulletin. 2(1): 2347-5447.

[3]Hazarika, P.; Nayak, D. R. and Balakrishnan, R. 2010. Ear, Nose, Throat and Head \& Neck surgery; Clinical and practical, 2nd ed. 317.

[4]Kanani, A.; Schellenberg, R.; Warrington, R. 2011. Urticaria and angioedema. Asthma and clinical immunology. Allergy 7(1):1-10.

[5]Wu, L. C. and Zarrin, A. A. 2014. The production and regulation of $\operatorname{IgE}$ by the immune system. Nature Reviews Immunology, 14: 247-259.

[6]Kovalszki, A.; Sheikh, J. and Weller, P. F. 2013. Eosinophils and Eosinophilia. In Clinical Immunology, principle \& practice, 4(2): 304.

[7]Venge, P. 2004 Review article: Monitoring allergic inflammation. Allergy, 59: 26-32.

[8]Hogan, S. P.; Rosenberg, H. F.; Moqbel, R.; Phipps, S.; Foster, P. S.; Lacy, P.; Kay, A. B. and Rothenberg, M. E. 2008. Eosinophils: Biological properties and role in health and disease. Clin Exp Allergy, 38: 709750.

[9]Rojelio, M. and Thomas, B. N. 2012. Evaluation and differential diagnosis of marked, persistent eosinophilia. Semin Hematol, 49(2): 149-159.

[10] Trung, N.; Tran, D. B.; Khatry, K. e.; Christine, K. and Ward, D. G. 2014. High blood eosinophil count is associated with more frequent asthma attacks in asthma patients. Annals of 
allergy, Asthma \& Immunology, Immunology, 1: 19-24.

[11] Parveen, T.; Begum, N. and Begum, S. 2009. Allergen Skin Test Reactivity and Serum Total IgE Level in Adult Bronchial Asthmatic Patients. J Bangladesh SocPhysiol, 4(1): 1-6.

[12] Chowdary, V. S.; Vinaykumar, E. C.; Rao, J. J.; Rao, R.; RamBabu, K. and Rangaman, V. 2003. Astudy on serum $\operatorname{IgE}$ and eosinophils in respiratory allergy patients. Indian $\mathrm{J}$ Allergy Asthma Immunol., 17(1): 2124.

[13] Patel, A. K. and Nagpal, T. P. 2014. Comparsion of blood absolute eosinophil count and nasal smear eosinophilswith symptoms and severity of clinical score in patients with allergic rhinitis. Indian J Allergy Asthma Immunol., 28(2): 74-77.

[14] SAS. 2012. Statistical Analysis System, User's Guide. Statistical. Version $9.1^{\text {th }}$ ed. SAS. Inst. Inc. Cary. N.C. USA.

[15] Foley, S. and Hamid, Q. 2009. Immunopathology of Allergic Airway Inflammation. In: Middleton's iv Holgate ST, Simons FER; 7th ed, Mosby Elsevier Philadelphia, USA, 473.

[16] Kindt, T. J.; Goldsby, R. A. and Osborne, B. A. 2007. Hypersensitivity Reactions. In Kuby Immunology, 6th ed.chapter15:371375.

[17] Kang, G.; Ju, Y. H.; Jung, J. H.; Ko, K. P.; Oh, D. K.; Kim, J. H.; Lim, D. H.; Kim, Y. H.; Jang, T. Y. and Kim, S. T. 2015. The Effect of PM10 on Allergy Symptoms in Allergic Rhinitis Patients During Spring Season. Int $\mathbf{J}$ Environ Res Public Health,(12):735-45.

[18] Scichilone, N.; Callari, A.; Augugliaro, G. Marchese, M.;Togias, A. and Bellia, V. 2011. The impact of age on prevalence of positive skin prick tests and specific $\operatorname{IgE}$ tests. $\mathbf{J}$ Respir Med., 105(5): 651- 658.

[19] AL-Yasiri, M. Y. K. 2014. Study some Immunological and Haematological changes upon workers of Vegetable Oils factory in Baghdad suffering from Hypersensitivity Type -1 . MSc Thesis, Collage sciences for women. University of Baghdad. Iraq, pp.1101.

[20] Huang, S.; Vasquez, M. M.; Halonen, M.; Martinez, F. D. and Guerra, S. 2015. Asthma, airflow limitation and mortality risk in the general population. EurRespir J., 45(2): 338-46.

[21] Khan, M.; Khan, M.A.; Shabbir, F. and Rajput, T. A.2013. Association of allergic rhinitis with gender and asthma. J Ayub Med Coll Abbottabad, 25(1-2):120-2.

[22] Pereira, P. R. and Lopes, C. 2013. A cross sectional assessment of allergic rhinitis and asthma control at an immunoallergology outpatient hospital setting using CARAT10 questionnaire. Rev Port Pneumol., 19(4):163-7.

[23] Marinas, J. E. C. and Yeung, J. 2015. Chronic Spontaneous Urticaria and Omalizumab as an Emerging Therapy. Int J ClinDermatol Res., 3(1): 45-49.

[24] AL-Mousawi, M. H. A. 2009. Measurement of immunoglobulins and some hematological changes in acute and chronic urticaria. B.Sc thesis. University Baghdad, pp:1-72.

[25] Manohar, S. and Selvakumaran, R. 2012. Estimation of serum immunoglobulin $\mathrm{E}$ (IgE) level in allergic asthma and allergic rhinitis patients before and after treatment. Euro. J. Exp. Bio., 2 (6):2199-2205.

[26] Söderström, L.; Lilja, G.; Borres, M. P. and Nilsson, C. 2011. An explorative study of low levels of allergen-specific $\operatorname{IgE}$ and clinical 
allergy symptoms during early childhood. Allergy,66(8):1058-64.

[27] Al-Taee, K. S. C. 2003. Immunological and microbiological study for asthmatic patients. M.S.c thesis. AL-Mustansiriyah university college of science, Iraq, pp:1-184.

[28] Yalcin, A. D. 2014. Advances in Anti-IgE Therapy. BioMed Res Int., pp 1-11.

[29] Kariyawasam, H. H. and Robinson, D. S. 2006. The eosinophil: the cell and its weapons, the cytokines, its locations. Semin RespirCrit Care Med., 27: 117-27.
[30] Walsh, E. R. and August, A. 2010. Eosinophils and allergic airway disease: there is more to the story. Trends in Immunology, 31: 39-44.

[31] Jagadeeshwar, K.; Venumadhav, V.; Sangram, V.; Sathavahana, C. V.; Sudha, R. and Vinaykumar, E. C. 2012. A Study on serum IgE Levels, Peripheral Eosinophil and Individuals symptom's in patients with noninfective rhinitis and asthma and related conditions. Int J Pharm Pharm Sci., 4(1): 88-92.

\section{دراسة الكلوبيولين المناعي الكلي وعد الخلايا الحمضة في أمراض الحساسية
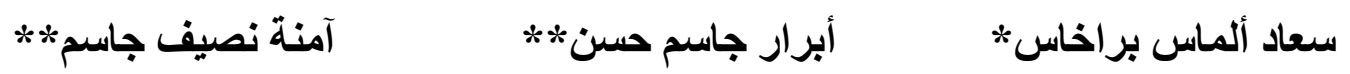

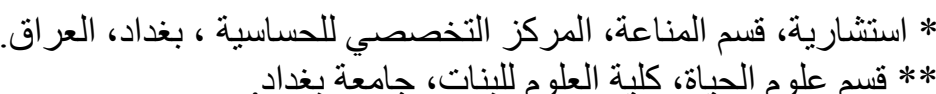

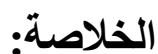

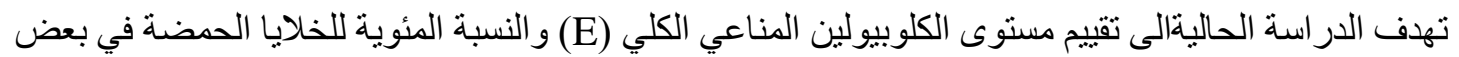

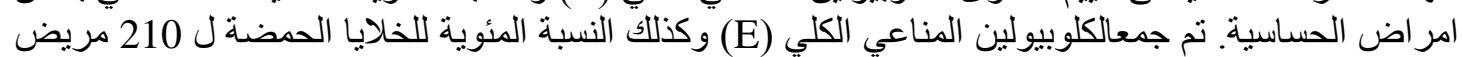

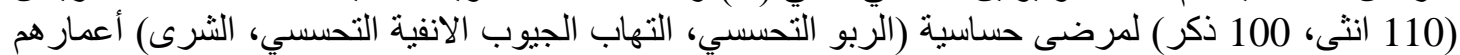

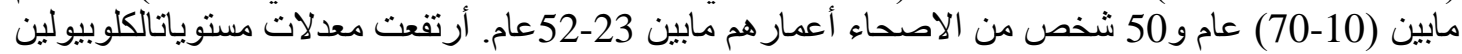

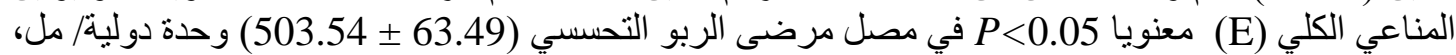

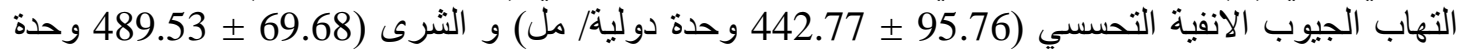

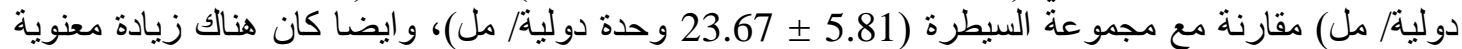

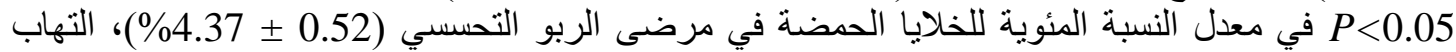

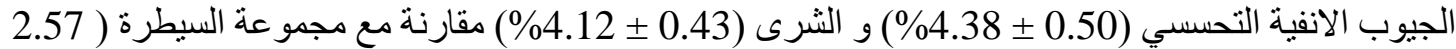

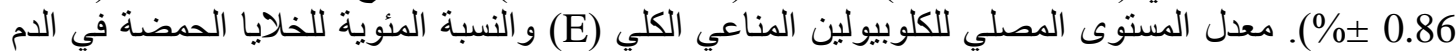
يمكن ان تكون مفيدة في تثخيص المبر الض اض الحساسية.

الكلمات المفتاحية: الربو التحسي، التهاب الجيوب الانفية التحسي، الثرى،الكلوبيولين المناعي الكلي(E)، الحمضات الكمات المغنات 